\title{
触 New Disease Reports \\ First report of leaf rust caused by Coleosporium solidaginis on Liatris pycnostachya (prairie blazing star)
}

N.C. Luecke* and K.M. Crawford

Department of Biology \& Biochemistry, University of Houston, Houston, TX 77204, United States of America

*E-mail: ncluecke@central.uh.edu

Received: 17 Jul 2019. Published: 13 Sep 2019. Keywords: fungal plant disease, grassland, Pucciniales

In November 2017, several individuals of prairie blazing star (Liatris pycnostachya; Fig. 1) were observed with symptoms of leaf rust and severe defoliation in La Marque, Texas (GPS coordinates 29 $23^{\prime} 30.8^{\prime \prime} \mathrm{N}$ $\left.95^{\circ} 02^{\prime} 21.6^{\prime \prime} \mathrm{W}\right)$. Symptoms were distributed across multiple leaf surfaces with no clear correlation with leaf age. The abaxial leaf surface had circular to angular spots surrounded by brown necrotic tissue (Fig. 2), and the adaxial leaf surface had bright yellow-orange rust pustules (uredinia) that were erumpent and 200 to $500 \mu \mathrm{m}$ in diameter. Urediniospores were broadly obovoid, amber in colour, and ovate (30-35 $\mu \mathrm{m}$ long $\times 15-25 \mu \mathrm{m}$ wide; $n=40$ ) with echinulate spore walls 1.3-1.5 $\mu$ m thick (Figs. 3-4).

Based on host information, the pathogen was identified as a Coleosporium species and based on morphology it was identified as $C$. solidaginis. As rust fungi cannot be cultured, Koch's postulates cannot be tested, so we proceeded with molecular methods of identification. DNA was extracted from urediniospores of two samples, and two separate nested PCR reactions were performed. The $28 \mathrm{~S}$ gene region of rDNA was initially amplified with Rust2inv (Aime, 2006) \& LR6 (Vilgalys \& Hester, 1990), and an additional PCR was conducted using the Rust28SF primers (Moranz et al., 2014) \& LR5 (Vilgalys \& Hester, 1990). PCR products were sequenced with primers Rust28SF and LR5 and the sequenced region shared $99-100 \%$ identity with a number of $C$. solidaginis isolates (e.g. BPI 877830, Sevier Co., USA; GenBank Accession No. MF769692; McTaggart \& Aime, 2018). The sequences generated in this study were deposited in GenBank (MN334696 and MN334697).

Liatris pycnostachya is an ecologically and economically important species. It is common in remnants of the threatened coastal tallgrass prairie and is a nectar source for grassland-obligate butterflies (Moranz et al., 2014). It is also grown commercially for ornamental arrangements and landscaping. The more common hosts of $C$. solidaginis, Solidago spp., are common prairie forbs, but have not been found hosting $C$. solidaginis at this site. To our knowledge, $C$. solidaginis has never been reported on $L$. pycnostachya. The presence of $C$. solidaginis on L. pycnostachya at this site is of particular concern given that (i) urediniospores disperse long distances by wind, (ii) its appearance on $L$. pycnostachya suggests that $C$. solidaginis now has another host, which may increase its spread, (iii) the spread of $C$. solidaginis in Texas prairies could harm important plant resources in an already threatened ecosystem, and (iv) host expansion of the rust may negatively affect commercial ornamental production of L. pycnostachya.

\section{Acknowledgements}

This work was supported by the National Science Foundation (Award \#DEB-1754287), Texas Ecolab, and the University of Houston.

\section{References}

Aime MC, 2006. Toward resolving family-level relationships in rust fungi (Uredinales). Mycoscience 47, 112-122. http://dx.doi.org/10.1007/S10267-006-0281-0

McTaggart AR, Aime MC, 2018. The species of Coleosporium (Pucciniales) on Solidago in North America. Fungal Biology 122, 800-809. http://dx.doi.org/10.1016/j.funbio.2018.04.007

Moranz RA, Fuhlendorf SD, Engle DM, 2014. Making sense of a prairie butterfly paradox: The effects of grazing, time since fire, and sampling period on regal fritillary abundance. Biological Conservation 173, 32-41. http://dx.doi.org/10.1016/j.biocon.2014.03.003

Vilgalys R, Hester M, 1990. Rapid genetic identification and mapping of enzymatically amplified ribosomal DNA from several Cryptococcus species. Journal of Bacteriology 172, 4238-4246. http://dx.doi.org/10.1128/jb.172.8.4238-4246.1990

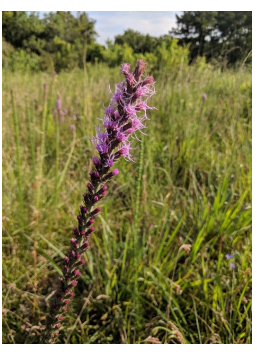

Figure 1

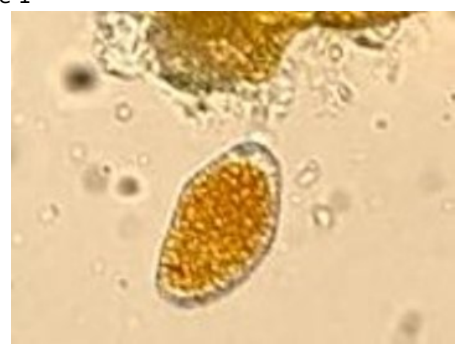

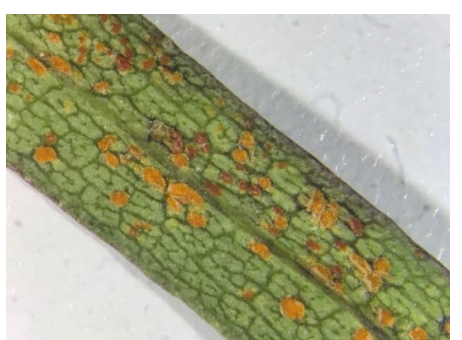

Figure 2

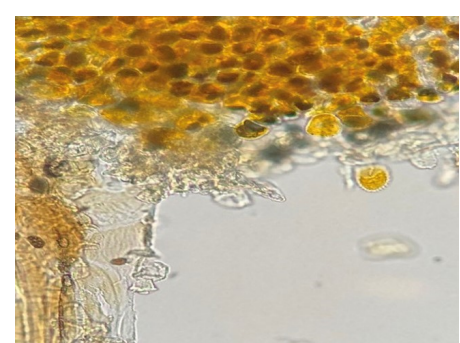

Figure 3

Figure 4

To cite this report: Luecke NC, Crawford KM, 2019. First report of leaf rust caused by Coleosporium solidaginis on Liatris pycnostachya (prairie blazing star). New Disease Reports 40, 10. http://dx.doi.org/10.5197/j.2044-0588.2019.040.010 